\title{
VEGETATION CHANGES AFTER LIVESTOCK GRAZING EXCLUSION AND SHRUB CONTROL IN THE SOUTHERN CHIHUAHUAN DESERT
}

\author{
Ricardo Mata-González,3, Benjamín Figueroa-Sandoval ${ }^{1}$, \\ Fernando Clemente ${ }^{1}$, Mario Manzano ${ }^{2}$
}

\begin{abstract}
Vegetation cover and production were evaluated after nearly 7 years of livestock grazing exclusion and shrub control in an area with a long history of heavy livestock grazing in the southern Chihuahuan Desert, Mexico. An exclosure was established to prevent livestock grazing. In half of the excluded area, the main shrub, Larrea tridentata, was mechanically controlled. Outside the exclosure, heavy livestock grazing occurred as customary and shrubs were not controlled. Absence of grazing resulted in 50\% higher grass cover and 35\% higher total biomass. Larrea tridentata cover was twice as high on the grazed area as on the ungrazed area. Vegetation cover was dominated by grasses (42\%) in the ungrazed area, whereas in the grazed area, cover was equally divided between grasses (28\%) and shrubs (27\%). Shrub control did not affect vegetation cover or herbage production. Multivariate analysis confirmed that inside the excluded area, shrub control had little impact on the plant community. The effect of grazing, however, clearly distinguished the community outside the exclosure from that inside the exclosure.
\end{abstract}

Key words: Altiplano Potosino-Zacatecano, central Mexico, Larrea tridentata, livestock exclosure.

The southernmost part of the Chihuahuan Desert, the Saladan subdivision, comprises arid portions of San Luis Potosí and Zacatecas in central Mexico (Fig. 1). Part of the Saladan subdivision is known as the Altiplano Potosino-Zacatecano. In this region, as well as in other areas of central and northern Mexico, extensive livestock grazing commenced on native rangelands during the Spanish colonization (1521-1810) to support the mining centers (Ezcurra and Montaña 1990, RomeroManzanares and García-Moya 1990, Dregne 2002). Over time livestock grazing has maintained importance in the area, because crop production is hindered by limited precipitation and infertile soils. However, excessive livestock grazing in the Altiplano PotosinoZacatecano and adjacent areas of central and north central Mexico has led to significant losses of vegetation cover and increases in soil erosion (Martinez-Morales and Meyer 1985, Romero-Manzanares and García-Moya 1990, Morales-García 1992, Aguado-Santacruz and García-Moya 1998).

In the northern Chihuahuan Desert, excessive livestock grazing has also been considered, either alone or in conjunction with other factors, a cause for loss of grassland area and advance of shrubs (Buffington and Herbel 1965, Kerley and Whitford 2000). Because excessive grazing may lead to losses in vegetation cover and production, it is often assumed that removal of livestock grazing in arid and semiarid rangelands results in increasing grass cover and herbage production as previously reported (Pieper 1968, Smith and Schmutz 1975, Anderson and Holte 1981, Valone and Sauter 2005). However, in other cases, removal of livestock grazing has not improved range productivity or vegetation cover (West et al. 1984, Beck and Tober 1985, Gibbens and Beck 1988, Omar 1991, Muscha et al. 2004).

In the northern Chihuahuan Desert, shrubs like Larrea tridentata have gained dominance in recent history (Buffington and Herbel 1965, Gibbens et al. 2005). In areas with L. tridentata at high density, forage production and grass cover tend to decrease (Beck and Tober 1985, Miller and Huenneke 2000) and the potential for soil erosion may increase (Abernathy and Herbel 1973). Control of L. tridentata is an option to promote recovery of the

\footnotetext{
${ }^{1}$ Campus San Luis Potosí, Colegio de Postgraduados, Iturbide No. 73, Salinas de Hidalgo, San Luis Potosí, 78600 México.

${ }^{2}$ Centro de Calidad Ambiental, Tecnológico de Monterrev, Ave. Eugenio Garza Sada 2501 Sur, Monterrey, Nuevo León, 64849 México.

${ }^{3}$ Present address: Ciencia Ecological and Environmental Consultants LLC, 3250 Belmont Court, Wellington, CO 80549. E-mail: ricardo.matagonzalez@gmail.com
} 


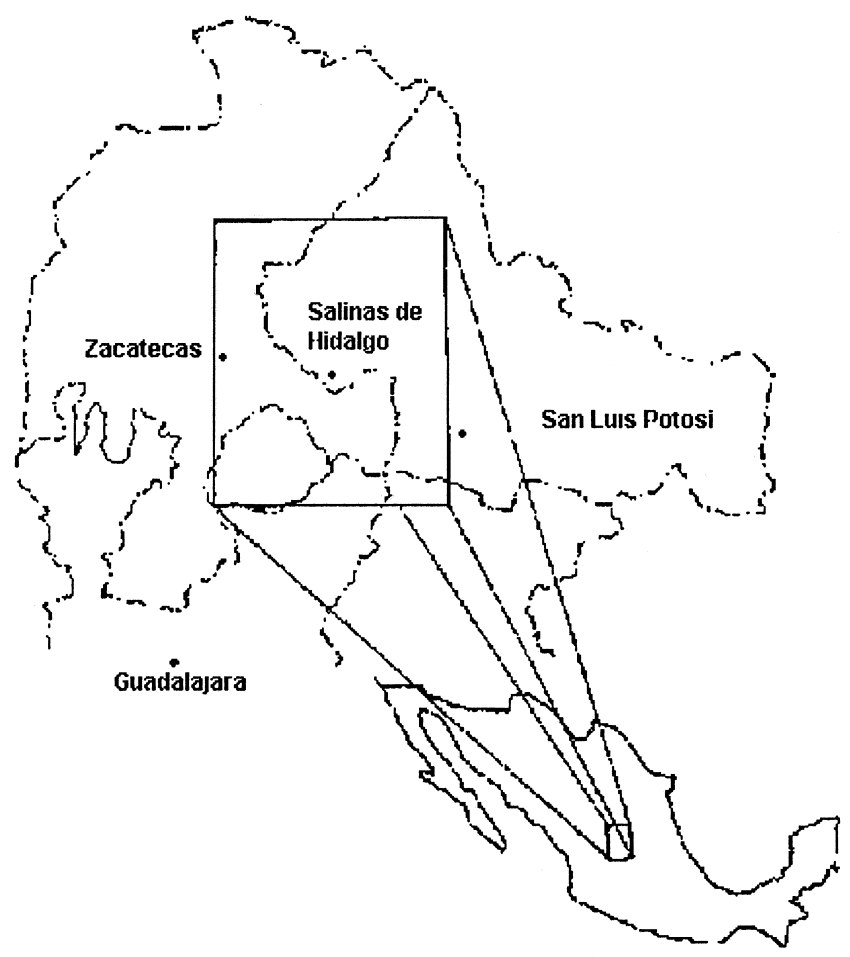

Fig. 1. Study area location near Salinas de Hidalgo, San Luis Potosí, within the Altiplano Potosino-Zacatecano, southern Chihuahuan Desert, central Mexico.

grassland area, but control efforts have not always been successful (Havstad et al. 1999, Rango et al. 2005).

Research on the impact of grazing and shrub control on vegetation of the Chihuahuan Desert has been predominantly conducted in the northern Trans-Pecos subdivision area of New Mexico and Texas. Compared to its northern counterpart, the southern Chihuahuan Desert is higher in elevation and tends to have higher precipitation and less temperature fluctuation (MacMahon 1979, Mata-González et al. 2002), suggesting that responses of vegetation to grazing and shrub control could also be different. However, few studies have been conducted on Mexican subdivisions that comprise the southern Chihuahuan Desert (Valverde et al. 1996). This study was conducted to determine the effects of removing livestock grazing and controlling $L$. tridentata on vegetation cover and herbage production in an area with a long history of heavy livestock grazing in the southern Chihuahuan Desert. We hypothesized that excluding livestock grazing and controlling shrubs would result in increased herbage production and cover.

\section{STUdy AREA}

The study was conducted on a communal property (ejido) about $8 \mathrm{~km}$ southeast of Salinas de Hidalgo, San Luis Potosí, in central Mexico at $22^{\circ} 37^{\prime} 44^{\prime \prime} \mathrm{N}, 101^{\circ} 42^{\prime} \mathrm{W}$ (Fig. 1). The altitude is $2185 \mathrm{~m}$; the mean annual temperature is $16^{\circ}-18^{\circ} \mathrm{C}$ with little month-to-month variation (Romero-Manzanares and GarcíaMoya 1990); and the long-term average annual precipitation is $391 \mathrm{~mm}$ concentrated in the summer months. Annual rainfall measurements during the years of this investigation (19861992) were $324,356,370,250,578,478$, and $562 \mathrm{~mm}$, respectively. The soil texture is sandy loam on the upper horizon, but soils are shallow with a petrocalcic horizon at $\leq 50 \mathrm{~cm}$. The vegetation was characteristic of a desert grassland, and the main grasses were Scleropogon brevifolius, Erioneuron grandiflorus, and Aristida divaricata. The dominant shrub was $L$. 
tridentata, with a density of ca. 3000 plants . $\mathrm{ha}^{-1}$ and an aboveground biomass production of $363 \mathrm{~kg} \cdot \mathrm{ha}^{-1}$ (Mata-González unpublished data). The fact that shrubs did not occur in compacted groups facilitated the identification of individual plants for density determinations. Although L. tridentata has multiple stems deriving from the crown, most of the time it was easy to determine whether those stems belonged to the same plant by simple inspection of the base.

Historically, rangelands in the study area have been heavily grazed (Romero-Manzanares and García-Moya 1990). This area supports communal grazing of cattle, sheep, goats, and horses in that order of importance. Therefore, the main forage removed consists of herbaceous species, although some subshrubs are also consumed. There is little control of the grazing pressure and it was not possible to obtain a specific figure for the stocking rate. However, stocking rates from 0.26 to 0.82 animal units $\cdot \mathrm{ha}^{-1} \mathrm{yr}^{-1}$ have been reported on similar ranges in the area, and those rates are higher than recommended for the area $(0.1$ animal units $\cdot \mathrm{ha}^{-1} \mathrm{yr}^{-1}$; Romero-Manzanares and García-Moya 1990).

\section{METHODS}

A square area of about 16 ha was fenced in February 1986 to exclude livestock grazing. The area was divided into 4 strips of equal size (each approximately $100 \times 400 \mathrm{~m}$ ). In 2 alternate strips, the aboveground growth of L. tridentata was cut close to ground level with a rotary mower. Although the mowing targeted L. tridentata, other shrubs were also mowed. Cut shrubs were removed from the site. In the other 2 strips L. tridentata was not removed. Outside the exclosure heavy livestock grazing occurred as customary, and shrubs were not removed. An area equivalent to the size of 2 strips was used for measurements of vegetation outside the exclosure. Therefore, the vegetation was treated in 3 ways: (1) livestock grazing excluded and shrub control (NG-NS), (2) livestock grazing excluded and no shrub control (NG-YS), and (3) livestock grazing permitted and no shrub control (YG-YS). Each treatment was imposed in an area of about 8 ha. We took care to ensure that soil and vegetation characteristics were similar for the 3 treat- ment areas at the time the study was initiated, but baseline data were not available.

Over time it became evident that L. tridentata was starting to regrow in the area where it had been previously controlled (NG-NS treatment), so early in 1991, the species' top growth was removed again. This time, plants were selectively and manually cut with axes (individual plant treatment) to eliminate the basal bud zone (crowns about $5-10 \mathrm{~cm}$ below ground) to discourage further regrowth.

In fall 1992, nearly 7 years after establishing the experiment, we evaluated all treatments by measuring vegetation cover and aboveground herbage production by species. Evaluations were conducted in the fall to reflect the maximum growth and recovery of vegetation, which reduced the possibility that herbaceous sampling reflected only the annual intake of livestock. Cover was estimated by the lineintercept method (Canfield 1941). Interception of grasses and forbs was measured on the line at ground level (basal cover) and interception of shrubs and subshrubs was measured at canopy-spread level (canopy cover). The length of transect lines was $20 \mathrm{~m}$ and interceptions were determined to the nearest $1 \mathrm{~cm}$. Eight lines were randomly placed within the area allocated to each treatment.

We estimated herbage production by clipping aboveground live biomass of herbaceous plants (including subshrubs) at ground level within $1-m^{2}$ quadrats. Three quadrats were randomly located along each of the $20-\mathrm{m}$ lines used for estimating cover. Therefore, 24 quadrats were sampled for the area allocated to each treatment. Clippings were collected by species; and samples were collected in paper bags, ovendried, and weighed. Relative biomass was calculated as a proportion of the total biomass represented by every species. This calculation was made to easily compare the contribution of every species to the total production within each treatment.

Each grazing/shrub removal treatment was applied to only 1 pasture, although every pasture was divided into 2 strips. Therefore, to make statistical comparisons we defined our populations as the individual pastures to which treatments were applied. As such, the samples (line intercepts and quadrats) within each population were considered replications to estimate the inherent variability of the population. Thus, statistical inferences are limited to 
TABLE 1. Cover (\%) by plant group and by species in grazed and ungrazed pastures, with or without shrub control. Estimations of cover were obtained nearly 7 years after treatments were imposed. Different letters indicate significant differences between treatment means at $P<0.05$. $\mathrm{T}=\operatorname{trace}(<0.1 \%$ but $>0)$.

\begin{tabular}{|c|c|c|c|}
\hline & $\begin{array}{c}\text { NG-NS } \\
\text { (ungrazed, } \\
\text { shrub controlled) }\end{array}$ & $\begin{array}{c}\text { NG-YS } \\
\text { (ungrazed, } \\
\text { shrub intact) }\end{array}$ & $\begin{array}{c}\text { YG-YS } \\
\text { (grazed, } \\
\text { shrub intact) }\end{array}$ \\
\hline GRassEs & $42.2 \mathrm{a}$ & $42.5 \mathrm{a}$ & $28.2 \mathrm{~b}$ \\
\hline Aristida divaricata & $11.1 \mathrm{a}$ & $15.5 \mathrm{a}$ & $0.2 \mathrm{~b}$ \\
\hline Scleropogon brevifolius & $7.6 \mathrm{a}$ & $10.1 \mathrm{a}$ & $14.2 \mathrm{~b}$ \\
\hline Erioneuron grandiflorum & $6.6 \mathrm{a}$ & $6.1 \mathrm{a}$ & $2.2 \mathrm{~b}$ \\
\hline Erioneuron pulchellum & 3.7 & 3.5 & 1.3 \\
\hline Cyclostachia stolonifera & $8.4 \mathrm{a}$ & $2.8 \mathrm{~b}$ & $9.3 \mathrm{a}$ \\
\hline Muhlenbergia villosa & 1.8 & 1.9 & 0.3 \\
\hline Lycurus phleoides & 1.4 & 0.6 & 0.2 \\
\hline Bouteloua gracilis & 0.1 & 1.9 & 0.1 \\
\hline Eneapogon desvauxi & $\mathrm{T}$ & $\mathrm{T}$ & 0.0 \\
\hline Leptochloa dubia & $\mathrm{T}$ & 0.0 & 0.0 \\
\hline Sporobolus airoides & 0.0 & 0.0 & $\mathrm{~T}$ \\
\hline SHRubs (INCLUDES SUBSHRUBS) & $7.2 \mathrm{a}$ & $11.3 \mathrm{a}$ & $26.6 \mathrm{~b}$ \\
\hline Larrea tridentata & $0.0 \mathrm{a}$ & $5.2 \mathrm{~b}$ & $12.1 \mathrm{c}$ \\
\hline Gutierrezia texana & 3.5 & 3.1 & 1.2 \\
\hline Jatropa dioica & 3.3 & 1.8 & 2.4 \\
\hline Artemisia mexicana & $0.3 \mathrm{a}$ & $0.5 \mathrm{a}$ & $5.5 \mathrm{~b}$ \\
\hline Haplopappus venetus & $0.0 \mathrm{a}$ & $0.1 \mathrm{a}$ & $4.2 \mathrm{~b}$ \\
\hline Opuntia spp. & 0.0 & 0.5 & 1.2 \\
\hline Opuntia imbricata & $\mathrm{T}$ & $\mathrm{T}$ & $\mathrm{T}$ \\
\hline FORBS & $4.8 \mathrm{a}$ & $2.8 \mathrm{a}$ & $0.7 \mathrm{~b}$ \\
\hline Zinnia acerosa & $3.2 \mathrm{a}$ & $1.7 \mathrm{a}$ & $0.5 \mathrm{~b}$ \\
\hline Sida procumbens & 1.2 & 0.7 & 0.1 \\
\hline Sphaeralcea angustifolia & $\mathrm{T}$ & $\mathrm{T}$ & $\mathrm{T}$ \\
\hline Hymenoxys odorata & $\mathrm{T}$ & $\mathrm{T}$ & 0.0 \\
\hline
\end{tabular}

aAnnual species

differences among pastures within our study area (Wester 1992, Valone and Sauter 2005). Statistical differences between treatments were determined by univariate ANOVA and LSD protected tests at $P<0.05$. These analyses were made for cover and aboveground production of individual species, groups of species (grasses, shrubs, and forbs), and vegetation totals. However, total cover was not calculated and analyzed because of the impracticality of adding basal cover from grasses and canopy cover from shrubs. Prior to statistical analyses, data were arcsin transformed to meet assumptions of heterogeneity and normality. In addition, discriminant analyses were conducted to determine multivariate differences among treatments including all the species as a mosaic (SPSS, Inc., 2000). We used relative biomass as the variable for multivariate analysis.

\section{RESUlTS}

Grass cover was $50 \%$ higher in the ungrazed areas compared to the grazed area $(P=$
0.03; Table 1). However, there were differences among individual grasses with respect to grazing treatments. Cover of $A$. divaricata and $E$. grandiflorum was higher in the ungrazed areas than in the grazed area, whereas cover of S. brevifolius was higher in the grazed area.

Shrub cover was 2.3- to 3.7-fold higher in the grazed area than in the ungrazed area $(P=$ 0.04; Table 1). Larrea tridentata cover was more than 2-fold higher in the grazed than in the ungrazed area. Other shrubs with higher cover in the grazed area were Artemisia mexicana and Haplopappus venetus. Larrea tridentata and the grass S. brevifolius contributed to most of the vegetation cover in the grazed area. Vegetation cover was dominated by grasses $(42.2 \%-42.5 \%)$ in the ungrazed parcels, but in the grazed area, cover was equal for grasses $(28.2 \%)$ and shrubs (26.6\%). Similar to grasses, forbs had higher cover $(P=0.01)$ in the areas where grazing was excluded.

In the 2 ungrazed treatments (NG-NS and NG-YS), shrub control did not affect total grass cover, total shrub cover, or total forb 
TABLE 2. Total herbage biomass and relative biomass by plant groups and by species in grazed and ungrazed pastures, with or without shrub control. Biomass determinations were made nearly 7 years after treatments were imposed. Different letters indicate significant differences between treatment means at $P<0.05$. $\mathrm{T}=$ trace $(<0.1 \%$ but $>0)$.

\begin{tabular}{lccc}
\hline & $\begin{array}{c}\text { NG-NS } \\
\text { (ungrazed, } \\
\text { shrub controlled) }\end{array}$ & $\begin{array}{c}\text { NG-YS } \\
\text { (ungrazed, } \\
\text { shrub intact) }\end{array}$ & $\begin{array}{c}\text { YG-YS } \\
\text { (grazed, } \\
\text { shrub intact) }\end{array}$ \\
\hline Total biomass $\left(\mathrm{kg} \cdot \mathrm{ha}^{-1}\right)$ & $504 \mathrm{a}$ & $562 \mathrm{a}$ & $396 \mathrm{~b}$ \\
Relative biomass $(\%)$ & & & 90.4 \\
GrassEs & 87.1 & 72.0 & $5.9 \mathrm{~b}$ \\
Erioneuron grandiflorum & $25.6 \mathrm{a}$ & $24.2 \mathrm{a}$ & $48.6 \mathrm{~b}$ \\
Scleropogon brevifolius & $16.0 \mathrm{a}$ & $12.0 \mathrm{a}$ & $7.4 \mathrm{~b}$ \\
Erioneuron pulchellum & $20.1 \mathrm{a}$ & $10.6 \mathrm{ab}$ & $26.1 \mathrm{~b}$ \\
Cyclostachia stolonifera & $11.0 \mathrm{a}$ & $13.7 \mathrm{a}$ & 2.2 \\
Muhlenbergia villosa & 4.6 & 2.9 & $0.0 \mathrm{~b}$ \\
Aristida divaricata & $8.8 \mathrm{a}$ & $5.4 \mathrm{a}$ & 0.0 \\
Lycurus phleoides & 0.8 & 3.2 & 0.0 \\
Leptochloa dubia & $\mathrm{T}$ & $\mathrm{T}$ & 0.0 \\
Bouteloua gracilis & $\mathrm{T}$ & 0.0 & $8.3 \mathrm{a}$ \\
SuBsHRuBs & $7.0 \mathrm{a}$ & $15.6 \mathrm{~b}$ & $4.4 \mathrm{a}$ \\
Gutierrezia texana & $6.8 \mathrm{a}$ & $12.4 \mathrm{~b}$ & $3.9 \mathrm{~b}$ \\
Artemisia mexicana & $0.2 \mathrm{a}$ & $3.2 \mathrm{ab}$ & 0.0 \\
Haplopapus venetus & 0.0 & $\mathrm{~T}$ & $1.1 \mathrm{~b}$ \\
ForBs & $3.9 \mathrm{a}$ & $7.0 \mathrm{a}$ & $0.0 \mathrm{~b}$ \\
Zinnia acerosa & $2.1 \mathrm{a}$ & $4.1 \mathrm{a}$ & 1.1 \\
Sida procumbens & 1.8 & 2.9 & $\mathrm{~T}$ \\
Sphaeralcea angustifolia & $\mathrm{T}$ & $\mathrm{T}$ & $\mathrm{T}$ \\
Solanum elaeagnifolium & $\mathrm{T}$ & $\mathrm{T}$ & 0.0 \\
Heterosperma pinnatum & $\mathrm{T}$ & 0.0 & 0.0 \\
Perezia nana & 0.0 & & 0.0 \\
Hymenoxys odorata & $\mathrm{T}$ & 0.0 \\
\hline
\end{tabular}

aAnnual species

cover $(P>0.05$; Table 1$)$. Most plant species were not affected by the shrub control. Only 1 grass, Cyclostachia stolonifera, had higher cover in the shrub-controlled area than in the shrub-intact area.

Total herbage production was about 35\% higher in ungrazed areas than in grazed areas $(P=0.01$; Table 2). However, the relative biomass of the grass group was not significantly affected by grazing $(P=0.15)$ because individual grasses had different responses. Aristida divaricata, E. grandiflorum, and Erioneuron pulchellum had higher relative biomass in ungrazed areas, whereas $S$. brevifolius and $C$. stolonifera had a relative biomass 2 to 4 times higher in grazed areas. Total forbs had greater relative biomass in protected areas than in grazed areas $(P=0.02)$. Subshrubs had higher relative biomass in the ungrazed, shrub-intact area than in the other 2 treatment areas $(P=$ $0.04)$.

Shrub control did not affect total biomass production in the 2 ungrazed areas $(P=0.18$; Table 2). Likewise, shrub control did not sig- nificantly affect the relative biomass of grasses and forbs $(P>0.05)$. However, shrub control reduced the relative biomass of subshrubs $(P$ $=0.01$ ), perhaps because these plants were also affected by the 1st shrub control event.

The multivariate analyses confirmed some trends observed in the univariate analyses. The treatments were significantly different (Wilks-Lambda criterion, $P=0.01$; SPSS, Inc. 2000). The confidence ellipses around the centroids of the treatments NG-NS and NGYS overlapped in the canonical scores plot (Fig. 2), indicating that shrub control did not substantially alter the assemblage of species within these 2 ungrazed communities. In contrast, the confidence ellipse of the treatment YG-YS was clearly separated from those of NG-NS and NG-YS, showing that grazing was responsible for the group separation.

\section{Discussion}

When the experiment was established, condition of the vegetation was similar for the 


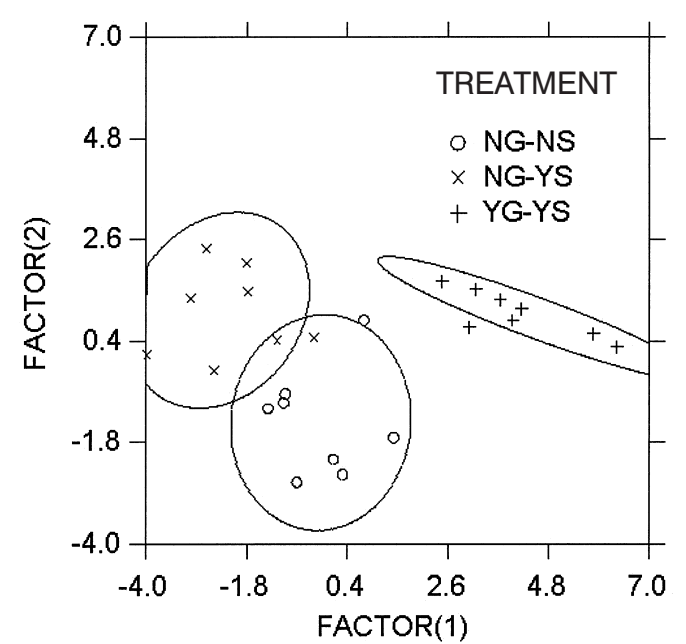

Fig. 2. Canonical scores plot for group separation of treatments based on discriminant analysis. The analysis was performed on relative biomass of all the species. NG$\mathrm{NS}=$ grazing suppression plus shrub control; NG-YS = grazing suppression and no shrub control; YG-YS $=$ no grazing suppression and no shrub control. Factor 1 is the linear combination of variables (species) that best discriminate among the groups. Factor 2 is the next best combination of variables (SPSS, Inc. 2000).

whole area of the 3 treatments. Therefore, the vegetation differences found at the end of the observation period were attributed to the treatments imposed. Most grasses responded favorably to grazing removal. This has been reported for other arid and semiarid environments (Pieper 1968, Smith and Schmutz 1975, Anderson and Holte 1981, Kerley and Whitford 2000, Anderson and Inouye 2001, Valone and Sauter 2005). However, a number of researchers have found little or no recovery of grasses after exclusion of grazing (West et al. 1984, Beck and Tober 1985, Gibbens and Beck 1988, Omar 1991, Muscha et al. 2004), often because drought overrides the exclusion effects.

The positive response of grass cover to exclusion of grazing that we observed was more pronounced than the response observed in the northern Chihuahuan Desert of New Mexico (Kerley and Whitford 2000, Valone and Sauter 2005). The vegetation of our study area, where annual precipitation is $391 \mathrm{~mm}$, may be more likely to recover than that of the northern Chihuahuan Desert, where annual precipitation is $233 \mathrm{~mm}$ (Mata-González et al. 2002). Valone and Sauter (2005) suggested that $>20$ years are necessary to achieve perennial grass recovery following exclusion of livestock grazing in the northern Chihuahuan Desert. Our results indicate that $<10$ years of grazing exclusion can effect grass recovery in the southern Chihuahuan Desert if precipitation for some years is above average, as occurred in our study. Unfortunately, there are no previous experiences of this nature to compare with our results. It is likely that under conditions of below-average precipitation the grass recovery in our area would be slower, but it still could be faster than in the northern Chihuahuan Desert. We concur with Pieper (1994), who suggested that it is difficult to generalize about the impact of livestock grazing on vegetation without considering other factors such as weather and plant community type.

Aristida divaricata and E. grandiflorum were favored by exclusion of grazing. Although these grasses have low palatability for cattle when mature, livestock grazing may limit their growth when they are young, green, and more palatable (Beck and Tober 1985). In contrast, S. brevifolium and C. stolonifera had higher cover and greater relative biomass on the grazed area, a result which indicates low consumption of these grasses by livestock (Beck and Tober 1985). The multivariate group separation confirmed that livestock grazing outside the exclosure was creating a community qualitatively different from that inside the exclosure. The community outside had less herbaceous vegetation and more shrub species. As indicated by Briske and Richards (1995), excessive livestock grazing indirectly favors the increase of unpalatable species because palatable species are selectively consumed.

Shrub control had no impact on herbage cover and production, and this was also confirmed by the multivariate analysis. Morton et al. (1990) reported that forage production increased after shrub control on areas with high L. tridentata density $\left(\geq 6000\right.$ plants $\left.\cdot \mathrm{ha}^{-1}\right)$, but not on areas with lower shrub densities. In our study, L. tridentata density was about 3000 plants $\cdot \mathrm{ha}^{-1}$, which may explain the lack of response of herbaceous species to the elimination of shrubs. Therefore, based on our data, we suggest that $L$. tridentata was not competitively limiting the growth of herbaceous vegetation prior to shrub control. Shrub density in the southern Chihuahuan Desert can be highly variable as it is in the northern Chihuahuan Desert (Miller and Huenneke 2000). 
Cover of Larrea tridentata was higher in grazed than in ungrazed pastures. However, controlling this shrub did not seem to benefit grasses. In agreement with this result, Sala et al. (1989) reported that removal of grasses in the Patagonian steppe favored shrub production, whereas removal of shrubs did not affect grass production. One difference between grasses and shrubs is their degree of adaptation to aridity. Desert shrubs are more drought tolerant than grasses, partly because of their deeper root system (Montaña et al. 1995). The adaptation of shrubs to arid systems makes shrubland communities very resilient and stable in comparison to grasslands (Heitschmidt and Pieper 1983, Rango et al. 2005).

The hypothesis that exclusion of livestock grazing would result in higher herbage production and cover was generally supported by our results. In contrast, the hypothesis that shrub control would increase herbage production and cover was not supported by our results. Our study was limited by its short duration, considering the long-term responses that grazing removal may require. Nevertheless, in an analysis of 236 studies worldwide comparing vegetation in grazed versus ungrazed sites, Milchunas and Lauenroth (1993) found that years of protection from grazing was not always a significant variable in determining vegetation changes. Long-term reports of vegetation change in livestock exclosures also have the limitation of not considering some short-term vegetation dynamics that may occur in response to grazing and precipitation conditions. Our conclusions are also limited by a potential lack of transferability to other sites, but this limitation is shared by similar studies (Valone and Sauter 2005). Nevertheless, these results represent a step forward in understanding vegetation management issues in contrasting areas of the Chihuahuan Desert.

Uncontrolled grazing can be a factor of range degradation as indicated by the replacement of grassland by shrubland area. A shrubdominated community has less desirable characteristics not only in terms of forage production but also from the perspective of soil and water conservation (Manzano and Návar 2000, Parizek et al. 2002). Nevertheless, livestock grazing has an economic and cultural value in the Altiplano Potosino-Zacatecano and in many other semiarid areas of the world. Therefore, judicious grazing management is necessary to ameliorate the deterioration of vegetation and soil in these areas.

\section{ACKOWLEDGMENTS}

We gratefully acknowledge Antonio GómezGonzález for initiating the exclosure. Assistance from Joel Juárez Bernal, Humberto Mata González, and Pedro Pablo Mata González is also gratefully acknowledged.

\section{Literature Cited}

Abernathy, G.H., and C.H. Herbel. 1973. Brush eradication, basin pitting, and seeding machine for arid to semiarid rangeland. Journal of Range Management 26:189-192.

Aguado-Santacruz, G.A., and E. García-Moya. 1998. Environmental factors and community dynamics at the southernmost part of the North American graminetum. I. On the contribution of climatic factors to temporal variation in species composition. Plant Ecology 135:13-29.

Anderson, J.E., AND K.E. Holte. 1981. Vegetation development over 25 years without grazing on sagebrushdominated rangeland in southeastern Idaho. Journal of Range Management 34:25-29.

Anderson, J.E., AND R.S. InOUYe. 2001. Landscape-scale changes in plant species abundance and biodiversity of a sagebrush steppe over 45 years. Ecological Monographs 71:531-556.

BECK, R.F., AND D.A. ToBER. 1985. Vegetational changes on creosotebush sites after removal of shrubs, cattle and rabbits. Bulletin 717, Agricultural Experiment Station, New Mexico State University, Las Cruces.

Briske, D.D., AND J.H. Richards. 1995. Plant responses to defoliation: a physiologic, morphologic and demographic evaluation. Pages 635-710 in D.J. Bedunah and R.E. Sosebee, editors, Wildland plants, physiological ecology and developmental morphology. Society for Range Management, Denver, CO.

Buffington, L.C., AND C.H. Herbel. 1965. Vegetational changes on a semidesert grassland range from 1858 to 1963. Ecological Monographs 35:139-164.

Canfield, R.H. 1941. Application of the line intercept method in sampling range vegetation. Journal of Forestry 39:388-394.

Dregne, H.E. 2002. Land degradation in the drylands. Arid Land Research and Management 16:99-132.

Ezcurra, E., And C. Montaña. 1990. Los recursos naturales renovables en el norte árido de México. Pages 297-327 in E. Leff, editor, Medio ambiente y desarrollo en México. Centro de Investigaciones Interdisciplinarias en Humanidades-UNAM. Porrúa, Mexico City.

Gibbens, R.P., And R.F. BEck. 1988. Changes in grass basal area and forb densities over a 64-year period on grassland types of the Jornada Experimental Range. Journal of Range Management 41:186-192.

Gibbens, R.P., R.P. McNeely, K.M. Havstad, R.F. BecK, AND B. Nolen. 2005. Vegetation changes in the Jornada Basin from 1858 to 1998. Journal of Arid Environments 61:651-668. 
Havstad, K.M., R.P. Gibbens, C.A. KNORR, And L.W. MURRAY. 1999. Long-term influences of shrub removal and lagomorph exclusion on Chihuahuan Desert vegetation dynamics. Journal of Arid Environments 42:155-166.

Heitschmidt, R.K., And R.D. Pieper. 1983. Integrated brush control and grazing management. Pages 89-95 in K.C. McDaniel, editor, Proceedings Brush Management Symposium. Society for Range Management, Denver, CO.

Kerley, G.I.H., AND W.G. Whitford. 2000. Impact of grazing and desertification in the Chihuahuan Desert: plant communities, granivores and granivory. American Midland Naturalist 144:78-91.

MacMahon, J.A. 1979. North American deserts: their floral and faunal components. Pages 21-82 in D.W. Goodall and R.A. Perry, editors, Arid land ecosystems: structure, functioning, and management. Volume 1. Cambridge University Press, Cambridge, U.K.

ManZano, M.G., And J. NÁVAR. 2000. Processes of desertification by goats overgrazing in the Tamaulipan thornscrub (matorral) in north-eastern Mexico. Journal of Arid Environments 44:1-17.

Martinez-Morales, R., And S.E. Meyer. 1985. A demographic study of maguey verde (Agave salmiana ssp. crassispina) under conditions of intensive utilization. Desert Plants 7: 61-64, 101-102.

Mata-González, R., R.D. Pieper, and M.M. Cardenas. 2002. Vegetation patterns as affected by aspect and elevation in small desert mountains. Southwestern Naturalist 47:440-448.

Milchunas, D.G., and W.K. Lauenroth. 1993. Quantitative effects of grazing on vegetation and soils over a global range of environments. Ecological Monographs 63:327-366.

Miller, R.E., AND L.F. Huenneke. 2000. The relationship between density and demographic variation within a population of Larrea tridentata. Southwestern Naturalist 45:313-321.

Montaña, C., B. Cavagnaro, and O. Briones. 1995. Soil water use by co-existing shrubs and grasses in the Southern Chihuahuan Desert, Mexico. Journal of Arid Environments 31:1-13.

Morales-García, D. 1992. Erosion eólica en agostaderos de la Altiplanicie Occidental Potosina. Professional thesis, Instituto Tecnológico Agropecuario No. 20 de Aguascalientes, Aguascalientes, Mexico.

Morton, H.L., F.A. IbarRa-F, M.H. Martin-R., and J.R. Cox. 1990. Creosotebush control and forage production in the Chihuahuan and Sonoran Deserts. Journal of Range Management 43:43-48.

Muscha, J.M., A.L. Hild, L.C. Munn, and P.D. Stahl. 2004. Impacts of livestock exclusion from Wyoming big sagebrush communities. Pages 176-182 in A.L. Hild, N.L. Shaw, S.E. Meyer, T.D. Booth, and E.D. McArthur, compilers, Proceedings-Seed and Soil Dynamics in Shrubland Ecosystems Symposium. RMRS-P-31. United States Department of Agriculture Forest Service, Ogden, UT.
OMAR, S.A. 1991. Dynamics of range plants following 10 years of protection in arid rangelands of Kuwait. Journal of Arid Environments 21:99-111.

Parizek, B., C.M. Rostagno, and R. Sottini. 2002. Soil erosion as affected by shrub encroachment in northeastern Patagonia. Journal of Range Management 55:43-48.

PiePER, R.D. 1968. Comparisons of vegetation on grazed and ungrazed pinyon-juniper grassland sites in southcentral New Mexico. Journal of Range Management 21:51-53.

. 1994. Ecological implications of livestock grazing. Pages 177-211 in M. Vavra, W.A. Laycock, and R.D. Pieper, editors, Ecological implications of livestock herbivory in the West. Society for Range Management, Denver, CO.

Rango, A., L. Huenneke, M. Bounopane, J.E. Herrick, AND K.M. Havstad. 2005. Using historic data to assess effectiveness of shrub removal in southern New Mexico. Journal of Arid Environments 62:75-91.

Romero-Manzanares, A., and E. García-Moya. 1990. Effects of browsing on growth and reproductive output of engordacabra in north central Mexico. Pages 317-324 in E.D. McArthur, E.M. Romney, S.D. Smith, and P.T. Tueller, editors, Proceedings-Symposium on cheatgrass invasion, shrub die-off, and other aspects of shrub ecology and management. General Technical Report INT-276, USDA Forest Service, Ogden, UT.

Sala, O.E., R.A. Galluscio, W.K. Lauenroth, and A. SORIANO. 1989. Resource partitioning between shrubs and grasses in the Patagonian steppe. Oecologia 81: 501-505.

Smith, D.A., AND E.M. SchmuTZ. 1975. Vegetative changes on protected versus grazed desert grassland ranges in Arizona. Journal of Range Management 28: $453-458$.

SPSS, INC., 2000. SYSTAT 10, Statistics I. SPSS, Inc., Chicago, IL.

Valone, T.J., AND P. Sauter. 2005. Effects of long-term cattle exclosure on vegetation and rodents at a desertified arid grassland site. Journal of Arid Environments 61:161-170.

Valverde, P.L., J.A. Zavala-Hurtado, C. Montaña, E. EzcurRa. 1996. Numerical analyses of vegetation based on environmental relationships in the southern Chihuahuan Desert. Southwestern Naturalist 41:424-433.

West, N.E., F.D. Provenza, P.S. Johnson, and M.K. OwENS. 1984. Vegetation change after 13 years of livestock grazing exclusion on sagebrush semidesert in west central Utah. Journal of Range Management 37:262-264.

Wester, D.B. 1992. Replication, randomization, and statistics in range research. Journal of Range Management 45:285-290.

Received 3 August 2005 Accepted 31 August 2006 